ELORE (ISSN 1456-3010), vol. 20 - 2/2013.

Julkaisija: Suomen Kansantietouden Tutkijain Seura ry.

[http://www.elore.fi/arkisto/2_13/leppalahti2.pdf]

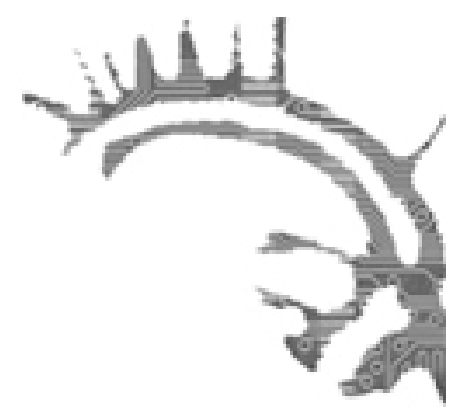

\title{
KIRJA-ARVIO
}

\section{UUSIA TUULIA KALEVALA-TUTKIMUKSESSA}

\author{
Merja Leppälahti
}

HÄMÄLÄINEN, NIINA 2012: Yhteinen perhe, jaetut tunteet. Lyyrisen kansanrunon tekstualisoinnin ja artikulaation tapoja Kalevalassa. Turun yliopiston julkaisuja C349. Turku: Turun yliopisto. <http://www.doria.fi/bitstream/handle/10024/85030/ AnnalesC349Hamalainen.pdf>. 337 sivua.

Kalevalaa koostaessaan Elias Lönnrot käytti eeppisten runojen lisäksi muita aineksia, kuten loitsuja ja lyyrisiä runoja. Niina Hämäläinen on tarkastellut väitöskirjassaan Lönnrotin toimitusprosessia ja Kalevalan lyyrisiä runoja 1800-luvun perhekeskustelun ja Lönnrotin perhekäsityksen kontekstissa. Hämäläinen on käsitellyt erityisesti Kullervo- ja Aino-runoja Kalevalan eri versioissa sekä vastaavia runoja Lönnrotin tuntemissa kansanrunoissa.

Kalevalan runokokonaisuuksina Kullervo- ja Aino-runot ovat vahvimmin Lönnrotin luomuksia, ja niissä Lönnrotin oma toimitustyö näkyy selvimmin. Vaikka suurin osa runosäkeistä on suoraan kansanrunoudesta, molemmat kokonaisuudet ovat koosteita useammasta eri runosta, jotka eivät ole kansanrunoina liittyneet samoihin henkilöhahmoihin. Lönnrot on käyttänyt lyyrisiä aihelmia syventämään ja selittämään kertovien runojen hahmoja ja sisältöä. 
Merja Leppälahti: Uusia tuulia Kalevala-tutkimuksessa

\section{MAAMMON MAHTI}

Lönnrotin Kullervo- ja Aino-runoissa käyttämät lyyriset runot kehystävät ja johdattelevat eeppisiä tapahtumia. Hämäläinen on tarkastellut lyyrisiä aihelmia temaattisina tunnekokonaisuuksina. Ne kuvaavat henkilöhahmojen sisäistä maailmaa ja tunteita, jotka myös selittävät heidän toimintaansa ja tekevät sen ymmärrettäväksi.

Lyyriset runot kuvaavat usein tunteita perheenjäsenten välillä. Perheenjäsenet, joihin lyyrisissä runoissa viitataan, ovat tavallisesti nimenomaan ydinperheen jäseniä: äiti, isä ja sisarukset. Lähiperheen vastakohtana runot esittävät esimerkiksi kylän naiset, anopin ja vieraan perheen. Sekä Kullervo- että Aino-runossa keskeinen perheenjäsen on äiti. Kalevalassa on myös positiivisia äitihahmoja, mutta Kullervo- ja Aino-runoissa äidin poissaolo tai ymmärtämättömyys tekee tämän syylliseksi lapsen onnettomuuteen. Kullervo tosin myös turvautuu äitiinsä ja saa tältä tukea, mutta Ainon äiti ymmärtää lapsensa hädän liian myöhään.

Lyyriset säkeet toimivat tapahtumien yhdistäjinä ja selittäjinä. Lönnrot sijoitti lyyriset jaksot usein henkilöhahmojen repliikeiksi; sekä Aino että Kullervo valittavat osaansa lyyrisin runoaihelmin. Lyyriset huolirunot tarjoavat lukijalle käsityksen Ainon tunteista, surusta joutua vanhan miehen vaimoksi, sekä Kullervon osattomuuden surusta, yksinäisyyden syiden ja siitä ulospääsyn etsinnästä. Lyyriset runot muovaavat henkilöhahmoista ajattelevia ja syvällisesti tuntevia inhimillisiä olentoja.

Lönnrot oli aktiivinen kirjoittaja ja kansanvalistaja, joka kirjoitti sekä säätyläisille että rahvaalle. Hämäläinen on tarkastellut Lönnrotin kirjoituksia ja muodostanut niiden pohjalta kuvaa Lönnrotin perhekäsityksistä. Lönnrot piti perheen keskushenkilönä äitiä, jonka tehtävänä oli opettaa ja kasvattaa lapset kunnon ihmisiksi, pitää yllä perheen kodikkuutta ja vaalia perhe-elämän puhtautta. Lönnrotin kirjoitusten valossa Hämäläinen tulkitsee Kullervon tarinan opettavaiseksi kertomukseksi myös säätyläisnaisille: Kullervon elämä oli alusta alkaen tuomittu epäonnistumaan, sillä ilman äitiä ja äidinmaitoa kasvaneesta lapsesta ei voi tulla kunnollista. Aino puolestaan suree, kun hänet määrätään liian nuorena lähtemään kotoa ja menemään vanhuksen puolisoksi. Ainon kohdalla Lönnrot toistaa Ainon itkua yhä uudelleen ja Hämäläinen yhdistääkin Ainon itkun myös hysteriaan, ajalle tuttuun naistentautiin. Ainon kuoltua tytön äiti varoittaa naittamasta tyttäriä vastoin näiden tahtoa. Kirjoitustensa perusteella Lönnrot itse näyttää kuitenkin olleen sitä mieltä, että tytön pitäisi hyväksyä epämieluisakin kosija ja tyytyä osaansa.

\section{KALEVALAN TOIMITUSPERIAATTEISTA}

Hämäläinen osoittaa, että Lönnrotilla oli selvä mielikuva siitä, millaista eeposta hän halusi olla kokoamassa. Kansanrunojen tuli kuvastaa muinaisuutta, vanhoja tapoja ja entisajan elämää - mutta sellaisena kuin kansallismielinen sivistyneistö sen halusi nähdä. Omienkin sanojensa mukaan Lönnrot valitsi runoista ja säkeistä parhaat. Moneen kohtaan tarjolla olisi ollut myös seksuaaliväritteisiä, aggressiivisia tai humoristisia säkeitä, mutta ne eivät ole sopineet siihen perinnetekstiin, jota Lönnrot halusi työstää. 
Vaikka Lönnrot usein lavensi runokokonaisuuksia esimerkiksi kertoa lisäämällä, hän myös typisti toimitustyössään perinteisiä merkityksiä ja ilmauksia sovinnaisempaan, sivistyneen lukijakunnan makua vastaavaan suuntaan. Esimerkkinä tästä Hämäläinen mainitsee mm. Syntymistään sureva -runon, jossa usein puhutaan sikiämisestä ja imettämisestä. Tällaiset ruumiilliset ilmaukset on Kalevalassa siivottu runosta pois.

Lönnrot laati Kalevalaa nimenomaan sivistyneistölle vaikkakin kansanomaisten ainesten pohjalta. Lukijakunnalle eeppisen kansanrunon konventiot olivat vieraita eikä suomen kielikään välttämättä ollut täydellisesti hallussa. Hämäläinen toteaa, että lukijat eivät ehkä olisi pystyneet ymmärtämään teosta ilman yleisölle tuttuja lyyristen runojen elementtejä, joiden avulla henkilöhahmojen toiminta kävi käsitettävämmäksi ja jotka täydensivät eeppisten runojen aukkoja ja viittauksia. Lönnrot ei korostanut eikä selitellyt kauniiden ja ihailtujen lyyristen tekstien mukanaoloa Kalevalassa, vaikka muuten kirjoitti paljonkin Kalevalan toimitustyössä tekemistään ratkaisuista.

\section{RAIKKAITA NÄKÖKULMIA}

Niina Hämäläinen nostaa tarkastelun keskiöön Lönnrotin työn Kalevalan koostamisessa. Hän tarkastelee Kullervo- ja Aino-runoston muuttumista Kalevala-tekstistä toiseen, alku-Kalevaloista nyky-Kalevalaan ja vielä sen jälkeen ilmestyneeseen lyhennettyyn Kalevalaan, joka oli tarkoitettu koulukäyttöön. Hämäläinen osoittaa, miten Lönnrotin käyttämät lyyriset runot syventävät eeppisten runojen henkilöhahmoja - Kullervon ja Ainon ihailtu traagisuus itse asiassa syntyy pitkälti lyyristen jaksojen kuvailussa.

Hämäläinen on syventynyt myös Lönnrotin muihin kirjoituksiin ja niihin perhettä ja naisen asemaa käsitteleviin keskusteluihin, joita käytiin 1800-luvun alkupuoliskolla. Hän sitoo Kalevalan koostamistyön aikalaiskontekstiin ja osoittaa, että Kalevalassa on nähtävissä heijastuksia koostamisaikanaan ajankohtaisen perhekeskustelun kysymyksistä ja Lönnrotin näkemyksistä perheestä.

Lönnrotin työtä Kalevalan kokoamisessa ovat aikaisemmin tarkastelleet erityisesti Väinö Kaukonen ja Matti Kuusi, jotka ovat keskittyneet säevertailuihin ja katsoneet taaksepäin muinaisaikoihin; Hämäläisen tutkimus avaa ansiokkaasti uudenlaisen näkökulman Kalevalaan tarkastellessaan Lönnrotin työn tuloksia hänen oman aikansa aikalaiskontekstissa.

Kirjan kansi on viehättävä. Kansikuvassa nähdään toisinnoilla täydennetty Vanhan Kalevalan aukeama, jonka päällä on säätyläisperheen perhekuva. Sitä vähän ihmettelen, miksi valokuvassa on Sofia ja Karl Backmanssonin perhe eikä Maria ja Elias Lönnrot neljän tyttärensä kanssa. Lönnrotin oma perhekuva olisi tässä tuntunut kovin luontevalta valinnalta.

Filosofian lisensiaatti Merja Leppälahti on turkulainen folkloristi, tietokirjailija ja kriitikko. 